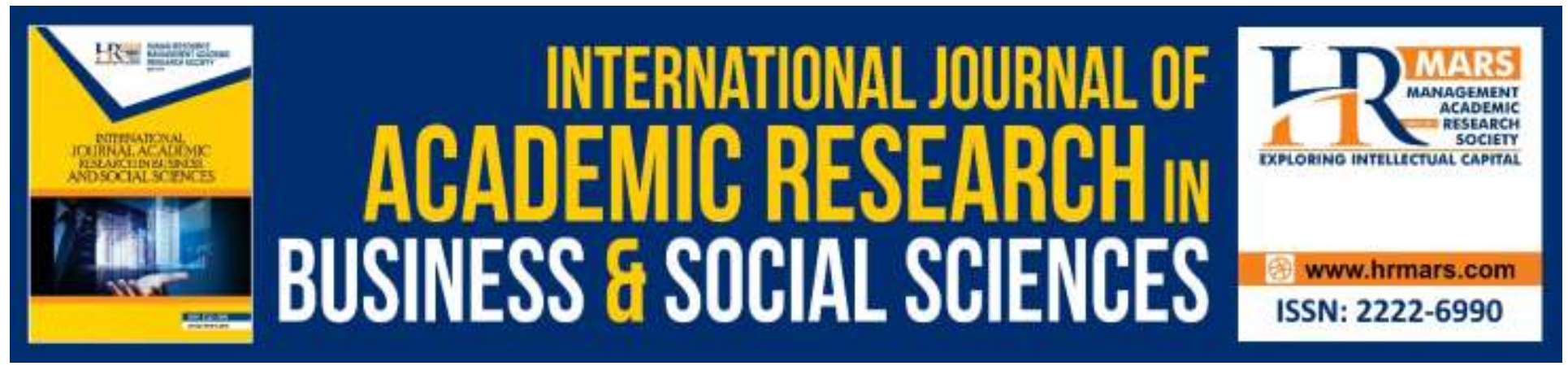

\title{
The Significance of Sabri Yunus Dramaturgy in Karoot Komedia X (Kk Comedy)
}

Mardiana Ismail, Mohd Effindi, Muhammad Faisal

To Link this Article: http://dx.doi.org/10.6007/IJARBSS/v10-i1/6830

DOI:10.6007/IJARBSS/v10-i1/6830

Received: 22 December 2019, Revised: 01 January 2020, Accepted: 15 January 2020

Published Online: 30 January 2020

In-Text Citation: (Ismail et al., 2020)

To Cite this Article: Ismail, M., Effindi, M., \& Faisal, M. (2020). The Significance of Sabri Yunus Dramaturgy in Karoot Komedia X (Kk Comedy). International Journal of Academic Research in Business and Social Sciences, 10(1), 161-170.

Copyright: (c) 2020 The Author(s)

Published by Human Resource Management Academic Research Society (www.hrmars.com)

This article is published under the Creative Commons Attribution (CC BY 4.0) license. Anyone may reproduce, distribute, translate and create derivative works of this article (for both commercial and non-commercial purposes), subject to full attribution to the original publication and authors. The full terms of this license may be seen at: $\underline{\text { http://creativecommons.org/licences/by/4.0/legalcode }}$

Vol. 10, No. 1, 2020, Pg. 161 - 170

http://hrmars.com/index.php/pages/detail/IJARBSS

JOURNAL HOMEPAGE

Full Terms \& Conditions of access and use can be found at

http://hrmars.com/index.php/pages/detail/publication-ethics 


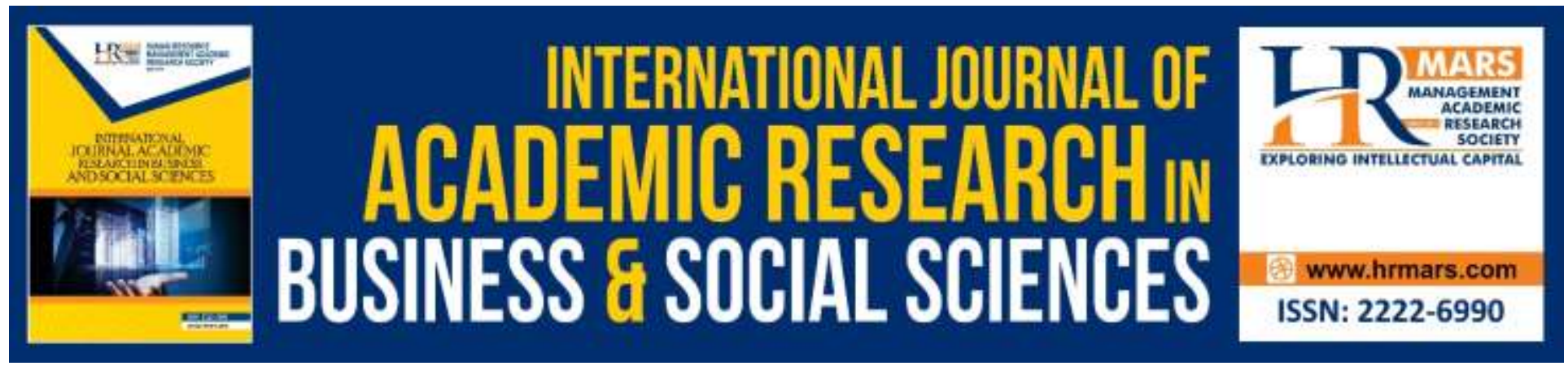

\title{
The Significance of Sabri Yunus Dramaturgy in Karoot Komedia X (Kk Comedy)
}

\author{
Mardiana Ismail \\ Faculty of Music and Performing Arts, Sultan Idris Education University, Malaysia \\ Mohd Effindi \\ Academy of Malay Studies, Universiti Malaya, Malaysia \\ Muhammad Faisal \\ Faculty of Music and Performing Arts, Sultan Idris Education University, Malaysia
}

\begin{abstract}
This article discusses the significance of Dramaturg in performing arts. Apart from that, this article aims to look into the standardised definition which needs to be modified to define Dramaturg specifically in the context of performing arts in Malaysia. In Malaysia, the term Dramaturg is rarely used by any performing arts researchers. Researchers are more inclined to use terms such as dramatists, directors and publishers to refer to an individual who visualised performances on stages, not realising that the term 'Dramaturg' itself has included all fields mentioned. The limited research resources on Dramaturg in Malaysia caused the involvement of a Dramaturg not being prioritised in any performing art. Due to that, this article chose a comedian, actor, host and director known as Mohd Sabri Yunus or his stage name Sabri Yunus as a research sample in this article. The data and written information in this article were obtained from the approaches practised in G.E. Lessing Dramaturg Model and Berger Humour Theories, which focuses on qualitative analysis to process the findings of this research. The findings of this article summarised the significance of Dramaturg as a highly-impactful essence in comedy performances in Malaysia. Through this documentation, Sabri Yunus' role as a Comedy Dramaturg can be interpreted, hence summarising the role of Dramaturg in helping to deliver values to performing arts through the issues and questions portrayed. Finally, from Dramaturgy, he will give impact on the society's lives and social.
\end{abstract}

Keyword: Dramaturg, Arthur Asa Berger Humour, Humour.

\section{Introduction}

This article justifies specifically on the role of a Dramaturg in comedy performances in Malaysia. The article stresses on a comedian, actor, host and director known as Sabri Yunus. As an individual 
involved in the filming industry, achieving Best Male TV Comedian award in Anugerah Seri Angkasa in the year 2005 and Popular Male Comedian award in Anugerah Bintang Popular in the years 1993, 1994, 1995, 1996 and 2000, qualifying him to be the best sample for this article. Based on the achievements, the researcher summarised specifically his role as a 'Comedy Dramaturg'.

The second purpose of this article is to use the role of a Dramaturg as highly-impactful in performances in Malaysia. In the context of this article, it is to ensure the roles of a Dramaturg in this region are accepted and on par with Western Dramaturgs such as Harley Granville Barker (November 25, 1877 - August 3, 1946), Gotthold Ephraim Lessing (January 22, 1729 - February 15, 1781), Bertolt Brecht (February 10, 1898 - August 14, 1956) and Kenneth Tynan (April 2, 1927 - Julai 26, 1980) and a few other figures (Luckhurst, M., 2006: 2). Therefore, the debates on Dramaturgy in Malaysia needs to be developed firsthand. Hence, this article in general aims to investigate the knowledge corpus on Dramaturgy in Malaysian context. The objectives of this article include interpreting Sabri Yunus' role as a Dramaturg in comedy performances in Malaysia and justifying the need to modify the 'standards' to detail the role of a Comedy Dramaturg in Malaysia.

\section{The Background of Drama and Dramaturgy}

By far, there are only a handful of previous research in relevance to the purpose of this article write up. Previous research on Dramaturgy is investigated comprehensively by Kerkhoven M.V (1988) who stated "...... an attempt to get a little bit closer to the heart of what European Dramaturgy could possibly be at that moment, there was the matter of different artistic points of view, which could be traced in the work of leading European artists of that moment". According to Kerkhoven, every activist in Europe has different artistic opinions. The same can be applied to the artworks from the Dramaturgs.

Kerkhoven (2009) in his article, A constant movement worried about the scenario in the development of arts in Europe in that period. The mixture of neoliberal political and economical issues had caused the declining moral values in performances. The article also discussed how the roles of Dramaturgs became important. The increasing tension on the economy, politics, and social with the emergence of rules and birocracy had caused the modifications to take place.

There are various research concepts on Dramaturg, where several of them are descriptive and documentative using the Dramaturg model approache as research methodology. Some examples are Library service as theatre: Using Dramaturgy to investigate attitudes to the retail and professional models of service by Cherry and Calvert (2012). The article wrote on the significance of a Dramaturg model in highlighting the attitude and behavior of librarians. It is generally known that librarians are bound with certain ethics in serving the clients. Therefore, through the article, the behavior of the librarians (referring to the chosen professional librarians as respondents in the article) were found to be different when serving the clients. In conclusion, the article analysed that every individual has various levels in attitude and behavior. It happens either consciously or unconsciously.

Meanwhile, the article Giving Clients a Backstage Experience: A Case of Dramaturgical Trouble in the Professional Performance of Drug Treatment by Andersen (2011) concluded, based on the 
Dramaturgical concept in which the professionals who treat in front of the stage (the symbol of an open space) was not successful in approaching problematic teenagers, but the professionals who provide treatment plan from behind the scenes (the symbol of a favourite space or place among teenagers) was successful in changing the teenager's problems.

The application of Dramaturgical concept is written in another research entitled Althusser's the Dramaturgy and the critique of Ideology. Balibar (2015) illustrated an ideologist which is Louis Althusser (1918-1990). Louis Althusser's ideology contributes to a very critical ideology. Through Balibar's explanation, Louis Althusser had conceptualised the theatrical ideology as a political agent by instilling the concept of political thinking in his theatrical performances. This is defined as 'materialist theatres'. However, what interests the researcher is to connect Louis Althusser's ideology with the similarities to the roles of a Dramaturg. By referring to an extract in the article written by Balibar, "The "theaters" involved here are theaters of politics, which also very much resemble theaters of war in a generalized sense" (p. 20). Lou is Althusser's ideology is referred to as something that opens the space and displays a transformation to the involvement of Dramaturgy in creating ideas for a performance.

To investigate on the next previous study, through the article written Peter Eckersall (2012), he sees the important indicator owned by Kris Verdonck through the creation of his works which combine the metaphorical elements with physical materials to quality performances. Verdonck had conducted re-invention on texts and familiarised them in Verdonck's performances. The concept developed by Verdonck can be considered as the work process of a Dramaturg.

The study of the concept of dramaturgy was less involved in the production of a drama because usually the director would act as the storyteller. This study provides the opportunity to raise drama as a better guide in the production. The role of the researcher in moving the concept of a dramaturg is not to be seen as the one who triggers the whole idea. Actors need specific guidance to look at the purpose of a drama's idea so that it does not deviate from the dramaturgy concept. This study will help directors, actors, and scriptwriters for better structured guidance.

The Instrumentation of the Research 'The Role of a Comedy Dramatrug Sabri Yunus in Karoot Komedia X (KK X)

For this part, qualitative method with case study is applied to obtain research data. The findings this research obtained from the answers to the unstructurised questions posed to the KK $X^{\prime}$ performance makers. Observation was conducted on the research sample which is Sabri Yunus and the performance of KK X. The approaches in Lessing Dramaturg Model and Berger Humour Theory are also applied.

\section{Asia Dramatrugy}

In Asian countries like Singapore, Indonesia, Phillippines, China, Korea, Sri Lanka and India, the roles of a Dramaturg in performing arts are developing further. A lot of Dramaturg experts have knowledge and skills, operating either in groups or separately. They want to develop performance as well as strengthening their roles on a piece or collective performances. This is proven with the symposium "Asean Dramaturg Network". This symposium was represented by Dramaturgs such as Ken Takiguchi (Singapore), Charlene Rajendran (Singapore), Alvin Tan (Singapore), Robin Loon (Singapore), Kok Heng Leun (Singapore), David Pledger (Australia), 
Lachlan Philpott (Australia), Alyson Campbell (Australia), Eko Supriyonto (Indonesia), Helly Minarti (Indonesia), Giselle Garcia (Phillippines), Li Yinan (China), Lim How Ngean (Malaysia), Max-Philip Aschenbrenner (Korea), Nanako Nakajima (Japan), Shintaro Fujii (Japan), Peter Eckersall (USA), Ruhanie Perera (Sri Lanka), Sankar Venkateswaran (India) and Yair Vardi (Israel). However, the situation is different in Malaysia. The development and understanding on the roles of a Dramaturg are still vague. From a report in Utusan Malaysia, Azman Ismail (2007) reported, "Dramaturg approach is still new in the context of performances in Malaysia, but not in Western countries". It is clear that many performing arts activists do not realise that they have been playing the role of Dramaturgs unconsciously. Therefore, this article looks into the issues on development and understanding on Dramaturgy in Malaysia.

Hence, starting from the reaction towards the issue mentioned beforehand, a platform to discuss the methods and approaches as a Dramaturg needs to be created. Behrndt (2015), in her article The aim of Dramaturgy in the Making: A User's Guide for Theatre Practitioners stated that:

"...... Dramaturgy is an important reference point for contemporary Dramaturgy', ......... include play development, dance, producing, translation, devising and production of plays. While there is a tendency to talk about 'method', 'tools', 'function' or 'role', and the conclusion can be a bit prescriptive with regards to what a 'good Dramaturg' should do or be, Dramaturgical work is presented as a complex process throughout" (p. 253).

From the extract above, Behrndt supported the idea of reviewing on the method, tools, function, or the roles of a Dramaturg. Through the results of the review, it reveals the difficulties faced by a Dramaturg to build the concept in an artwork or performance. The same can be said to the hardships faced by the Dramaturgs in Malaysia. As a country which consists multiracial and multicultural citizens, it is undeniable that a Dramaturg must be daring to try something new, to get out from the conventional thinking when creating and producing an artwork or performance. They need to be confident and brave enough to work inter-discipline and inter-racially. Factors such as language, culture and geographical factors are also challenging for a Dramaturg in Malaysia.

In an attempt to explore the renewal that needs to be delved further by Malaysian Dramaturgs, they need to face the issue of professional relationships with the performance maker (Behrndt, 2015: 254). Behrndt (2015) stated that, Dramaturgs and the performance maker (theatre directors, choreographers, artists, creative directors, publishers, curators, programmers and other related fields) need to have communication skills. Without this joint network, all works or performances will not work according to the plans and lose their systematic values. According to her, "........ Dramaturgcal work is about relationships: 'this is a relationship, a dialogue, an interrelation between two or more people with the aim of creating or developing a piece of performing artwork" (p. 254).

That aside, it is a dissatisfying situation when little exposure is given in the system of performing arts education, causing the halt in understanding Dramaturgy. When no focus is given in formal situations, surely there will be no practicality involved. This needs to be attended to by preparing programmes within the curriculum which pointing towards Dramaturgy education. If compared to a few institutions and universities abroad such as Columbia University's School of Arts, Carnegie Mellon University, Yale University, The American Repertory Theater, Moscow Aer 
Theater School and Institute for Advanced Theater Training have established Dramaturgy programmes in their education system on performing arts within their higher institutions.

According to Catherine Sheehy (2010), Chairwoman of the Department of Dramatugy and Dramatic Critisism, Yale University in a YouTube recording, " ...... students in their Diploma to Doctor of Philosophy levels are encouraged to enroll in Dramaturgy programmes officially as a complement to their study in performing arts. The students are exposed to Dramatic Structure, Theories of Representation, Aesthetics, Dramatic Literature and Theater History, and Practical Dramaturgy".

That being the case, with the knowledge on the roles of a Dramaturg, anyone can apply their knowledge and skills when working together with the performance makers in the performing arts industry (Behrndt, 2015: 254). With that, surely an artwork or a performance will have unique characteristics, exhibiting a variety in performance styles. They will also add on fresh look within the art itself, making it more exclusive. The same thing can happen to comedy performances in Malaysia if the roles of a Dramaturg are expanded.

This article also reacts to the suggestion from the Head of Director of Istana Budaya, Datuk Mohamed Juhari Shaarani in an interview with Mstar Online, "Istana Budaya wishes for the comedians to not touch on the issues of religious beliefs in their performances. The comedians in this country are advised to put some boundaries, and not interfering in any sensitive issue especially on religions and races in their performances, specifically in Istana Budaya. All productions who are given the opportunity to perform on prestigious stages like Istana Budaya need to conform to the rules and regulations provided to prevent any conflict even as jokes. ..... and other sensitive issues as not to raise any conflict" (Mohd Al Qayum Azizi, 2014).

Reaction is important to exist in a performance, as it is also one of the roles of a Dramaturg. As a Dramaturg, that individual will evaluate, give responses, become the intermediator or a reference to consider Istana Budaya's needs, and also the message the Dramaturg wishes to convey through their performances.

\section{The Concept of Dramaturgy Globally}

'Dramaturgy' refers to the art or drama writing techniques displayed in the form of theatrical art. The word 'Dramaturg' originated from Greece word 'Dramaturge' which means the teachings in dramatical arts. From more clear meaning to connect it with the performing art activities, Dramaturgy refers to the artwork arrangement techniques dramatically.

In this context, through the definition from Kamus Komprehensif Bahasa Melayu (Arbak, 2005), 'drama' refers to stage acting, television, radio, film, and acting. Now, the meaning of Dramaturgy differs according to the fields chosen as its scope of work. However, the roles of a Dramaturg are the same, which is as a drama artist or the director of a drama. Aside from being involved in drama writing, Dramaturgs also refer to the individuals who create and produce dramatical elements such as technical, sound, acting and movement for a drama writing. Thus, the roles of Dramaturgs as a whole are to control the actions, communication qualities, situation and the greatness of the overall performance. The same can be said to plaing the role of humans' conflicts arrangement for the actors and actresses, and also shaping the projection of the dialogues spoken and acted upon. 
In Malaysia, the word 'Dramaturg' is rarely used by any performing arts researchers. Other researchers are more inclined to use terms such as dramatists, directors and publishers to refer to the individuals who visualise performances on-stage, while the term Dramaturg actually summarises the whole jobscopes. They often group the term Dramaturg with several specific fields such as sociology, politics, and philosophy. For instance, Aristotle (384-322 BC), a Greece philosophical figure who was famous with his work "Poetics" had spread his observations on the appearances of the drama that have tragic endings or comedy stories with the concept of Dramaturgy.

Meanwhile, Burke, K. D. (May 5, 1897 - November 19, 1993) stated that life is not like a drama, but life itself is a drama, and it was from there that the concept of 'dramatism' was introduced. The main motive of introducing the concept of 'dramatism' is to give logical explanations to the functions of linguistic social and the language symbolism into the social lives of the society. Through the concept of 'dramatism', another writer on sociology Erving Goffman (June 11, 1922 - November 19, 1982) was attracted to the Burke's dramatism theory, prompting him to study Dramatism. Finally, he succeeded in completing a book on sociology theories entitled "The Presentation of Self in Everyday Life". The book promotes the concept of Dramaturgy in the articles on psychology and sociology. Another significant pioneer in the concept of Dramaturgy is Gotthold Ephraim Lessing (January 22, 1729 - February 15, 1781) who also contributed in the writing of the book "Hamburg Dramaturgy" which was written between the years 1767 and 1769. Eugenio Barba (October 29, 1936), a writer from Italy who was also a theatre director in Odin Theatre and International School of Theatre Anthropology, Denmark stated that, "A theatre which is able to speak to each spectator in a different and penetrating language is not a fantastic idea, nor a utopia...." through his book entitled "On Directing and Dramaturgy: Burning the House". He also defined Dramaturgy as the accumulation of actions not restricted to the actors' movements, but also consists of the actions related to the scenes, music, lighting, actors' vocals, voice effects, and objects used in performances. Further stated by Barba, Dramaturgy can only be defined from a written drama texts and the processes of a theatre performance which involve all the characters (Harymawan, 1993: 5-7).

Harymawan added that based on this definition, Dramaturgy debates on the process od creating theatres starting from the write-up to the staging of the play. Therefore, Harymawan shared the formula to Dramaturgy (1993: 3) to elaborate further on the roles of a Dramaturg which consists of $4 \mathrm{M}$. The first $\mathrm{M}$ is 'Mengkhayalkan' (Mesmerising); the second $\mathrm{M}$ is 'Menuliskan' (Writing); the third $M$ is 'Memainkan' (Playing); and the fourth $M$ is 'Menyaksikan' (Watching). Harymawan suggested the Dramaturgs to learn all four (4) processes mentioned before as the knowledge of "Drama Laws".

The Crossover of the Application of Berger Humour and Lessing Dramaturgy Model Used By Sabri Yunus In Karoot Komedia

In this article, Berger Humour theory is a mechanism to support the idea of comedy enlisted in the directorial, script-writing, acting, and hosting of Sabri Yunus. Meanwhile, the second aspect uses Lessing Dramaturgy Model as a crossover to create and produce KK Comedy. Refer to Chart 1.1 which is the Conceptual Research on the Importance of the Roles of a Dramaturg in Comedies. The result of the crossover in Chart 1.1 concludes the Comedy Dramaturg Sabri Yunus playing the 
role as the Researcher, Creator and Builder who uses the idea of language humour, identity humour, action humour, and logical humour to buils the concept of the KK Comdey performances. Lastly, Sabri Yunus produces a KK Comedy performance by applying the combined elements of Dikir Barat with Sitcomes to produce Karoot Komedia Comedy. 
INTERNATIONAL JOURNAL OF ACADEMIC RESEARCH IN BUSINESS AND SOCIAL SCIENCES

Vol. 10, No. 1, Jan, 2020, E-ISSN: 2222-6990 @ 2020 HRMARS

Chart 1.1 Conceptual Research of Sabri Yunus's Dramaturgy for Karoot Komedia Comedy
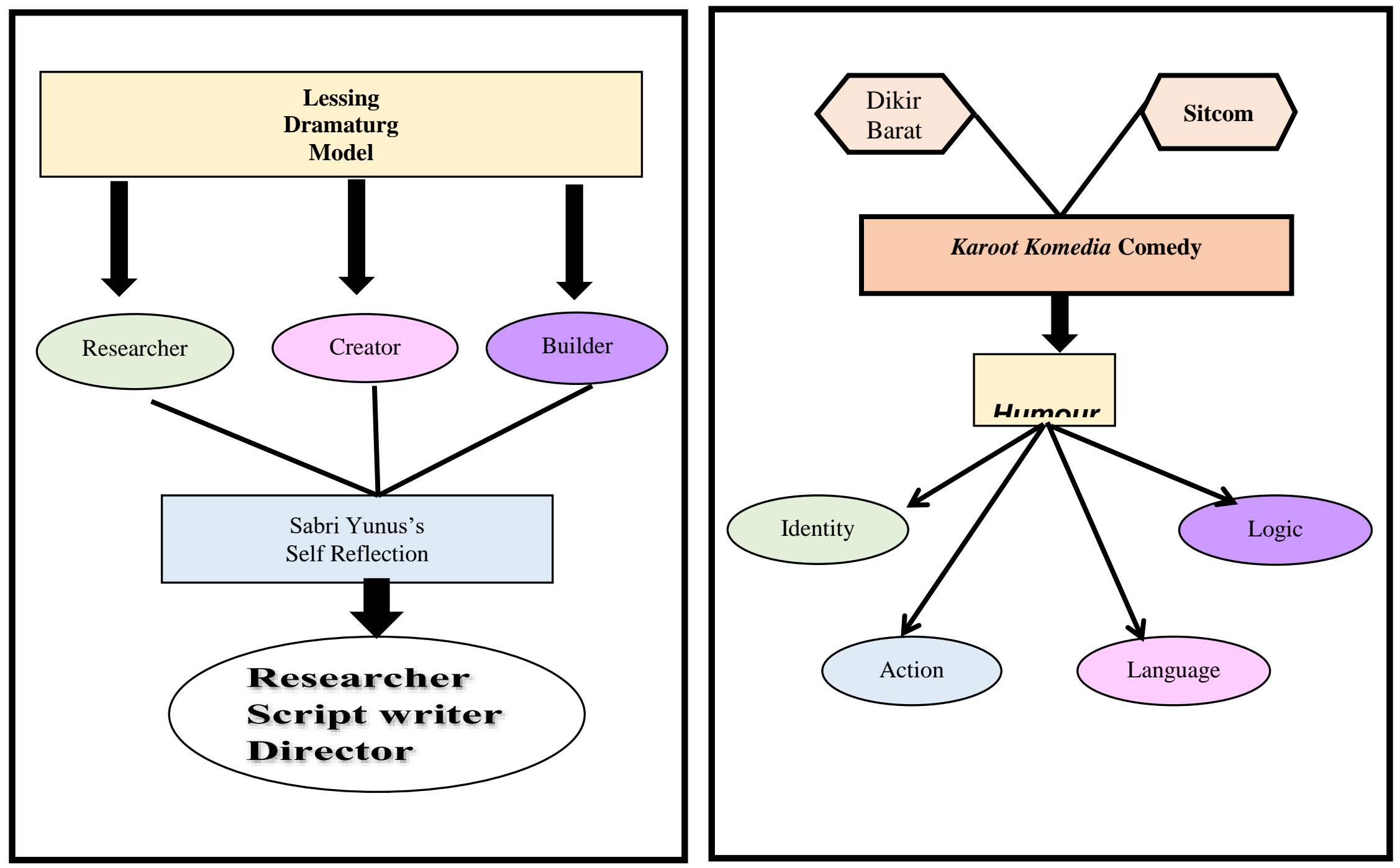
INTERNATIONAL JOURNAL OF ACADEMIC RESEARCH IN BUSINESS AND SOCIAL SCIENCES

Vol. 10, No. 1, Jan, 2020, E-ISSN: 2222-6990 C 2020 HRMARS

\section{Acknowledgement}

Deep appreciation and gratification for several individuals involved in data contribution throughout the process of this research such as Dr Mohd Effindi bin Samsuddin from Universiti Malaya, Encik Sabri Yunus, En Sulhie and Encik Hussin Saaban who helped in completing this research.

\section{Corresponding Author}

Mardiana binti Ismail

Faculty of Music and Performing Arts

Sultan Idris Education University

35900 Tanjong Malim

Perak, Malaysia

Email: mardiana@fmsp.upsi.edu.my

\section{References}

Qayum, Al. (2014) Utusan Malaysia Online. Diterbitkan: Selasa, 13 Mei 2014

Barba, E. (2010). On Directing and Dramaturgy:Burning The House. New York: Routledge Publications

Behrndt, S. K. (2015). Dramaturgy in the making: a user's guide for theatre practitioners. Journal Studies in Theatre and Performance, 35(3), 253-254.

Berger, A. A. (2012). An Anatomy of Humor. United States of America: Transaction Publishers.

Charlene, R. (2016). Symposium Asian Dramaturgy Network, Singapore. 23-24 April 2016.

Hadaway, R. (2015). Dramaturgy: Kurt Well's Street Scene': An American Opera and the American Immigrant's Experience. Tesis yang tidak diterbitkan.

Hartono, L. (2015). Teknik Humor dalam Film Warkop DKI. Jurnal e-Komunikasi, 3(1).

Harymawan. (1988). Dramaturgii. Bandung: CV Rosda.

Hussain, S. (1981). Sejarah Kesusasteraan Melayu. Kuala Lumpur:Dewan Bahasa dan Pustaka

Indrayuda, I. (2015). Continuity of Tradition Dance: Acedemicians' Intervention on Artists and Performing Arts Groups. Harmonia: Journal of Arts Research and Education, 15(2).

Ismail, A. (2007) Utusan Malaysia Online. Diterbitkan: Isnin, 30 Julai 2007

Lessing, G. E. (1962). Hamburg Dramaturgi. US: Dover Publications

Marianne, V. K. (2009). A constant movement. Journal of the Performing Arts, Vol 14, Issue: 3, pp. 7-11

Romanska, M. (2016). The Routledge Companion to Dramaturgy. New York: Routledge Publications

Sugiarto, V. D. (2016). Teknik Humor dalam Film Komedi yang Dibintangi oleh Stand Up Comedian. Jurnal e-Komunikasi, 4(2).

Trencsenyi, K. (2015). Dramaturgy in the Making: A User's Guide for Theatre Practitioners. London: Bloomsburry Publishing 